\title{
FEATURES OF CORONARY ARTERIES CHANGES IN PATIENTS WITH ACUTE MYOCARDIAL INFARCTION DEPENDING ON THE PRESENCE OR ABSENCE OF CONCOMITANT DIABETES MELLITUS TYPE 2
}

\author{
MD Zhuravlova M. I., \\ Professor Kravchun P. G., \\ Professor Ryndina N. G., \\ Associate Professor Tytova G. Yu. \\ Ukraine, Kharkiv, Kharkiv National Medical University;
}

DOI: https://doi.org/10.31435/rsglobal_ws/31052019/6514

\section{ARTICLE INFO}

Received: 07 March 2019

Accepted: 13 May 2019

Published: 31 May 2019

\section{KEYWORDS}

acute myocardial infarction, diabetes mellitus type 2, coronary angiography.

\begin{abstract}
The article analyzes the features of coronary arteries changes in patients with acute myocardial infarction (AMI) depending on the presence or absence of concomitant diabetes mellitus (DM) type 2. 60 patients with AMI and concomitant DM type 2 who were treated at the infarctional department of Kharkiv City Clinical Hospital No. 27 (Kharkiv, Ukraine) and cardiology department of the Kharkiv Clinical Hospital on Railway Transport №1 (Kharkiv, Ukraine) were investigated. In order to assess the status of the coronary flow, all patients in both groups underwent coronary angiography. The proportion of cases with multi-vessel lesions of coronary arteries exceeded the proportion of cases with one and twovessel lesions of coronary arteries in patients with acute myocardial infarction and type 2 diabetes.
\end{abstract}

Citation: Zhuravlova M. I., Kravchun P. G., Ryndina N. G., Tytova G. Yu. (2019) Features of Coronary Arteries Changes in Patients with Acute Myocardial Infarction Depending on the Presence or Absence of Concomitant Diabetes Mellitus Type 2. World Science. 5(45), Vol.2. doi: 10.31435/rsglobal_ws/31052019/6514

Copyright: (C) 2019 Zhuravlova M. I., Kravchun P. G., Ryndina N. G., Tytova G. Yu. This is an openaccess article distributed under the terms of the Creative Commons Attribution License (CC BY). The use, distribution or reproduction in other forums is permitted, provided the original author(s) or licensor are credited and that the original publication in this journal is cited, in accordance with accepted academic practice. No use, distribution or reproduction is permitted which does not comply with these terms.

Introduction. Coronary heart disease (CHD) and its forms is a key point not only in the structure of mortality, but also causes sustained loss of ability to work among the +population [1]. Multicenter studies show that the most threatening form of CHD is acute myocardial infarction (AMI), which occurs due to destabilization of the atherosclerotic plaque in $98 \%$ of cases [2].

High prevalence of violations of carbohydrate metabolism - from impaired glucose tolerance $(22.4 \%)$ to diabetes mellitus (DM) type $2(44.9 \%)$ - is seen in patients with AMI. The frequency of cardiovascular events correlates with the severity of diabetes [3].

Angiography of coronary arteries is a basic method for the diagnosis and treatment of various forms of CHD, including AMI [4]. However, discussion continues on the actualization of the tactics of reperfusion therapy in the detection of comorbid pathology, including AMI occurring on the background of DM type 2, as well as a further decrease in mortality in such patients after percutanious intervention $[5,6]$

Purpose of the study: to evaluate the peculiarities of coronary arteries changes in patients with acute myocardial infarction depending on the presence or absence of concomitant type 2 diabetes mellitus.

Materials and methods. 60 patients (mean age 64, $33 \pm 1.72$ years) were examined for AMI with ST elevation that were treated at the infarction department of Kharkiv City Clinical Hospital №27 and Kharkiv Clinical Hospital on Railway Transport №1.

The patients were divided into groups depending on the presence of concomitant type 2 diabetes. Group 1 included patients with AMI and associated DM type $2(\mathrm{n}=28)$. 2nd group consisted of patients with isolated AMI $(\mathrm{n}=32)$. 
In order to assess the status of the coronary flow, all patients in both groups have coronary angiography. Intervention was carried out with the consent of the patient and in the absence of contraindications (allergy, renal failure, pregnancy, disruption of blood coagulation, lack of contact with the patient due to violations of consciousness). Coronary angiography evaluated status of major coronary arteries (CA): the left main coronary artery, the right coronary artery (RCA), left anterior descending coronary artery (LAD), circumflex artery (CX). Presence of multiple lesions and the number of affected arteries were evaluated. To determine the degree of stenosis, we used angiography classification of atherosclerotic lesions of the arteries: I - stenosis to $50 \%$ of the lumen; II - stenosis from 50 to $75 \%$; III - stenosis from 75 to $90 \%$; IV - stenosis more than $90 \%$ (subocclusions or occlusion). The narrowing of the left main coronary artery was considered to be hemodynamically significant in the stenosis of $\geq 50 \%$, and for stenoses of other major CAs, more than $70 \%$ [7].

In order to establish the diagnosis of AMI, the selection of patients for coronary angiography according to indications with subsequent percutaneous interventions was used the Order of the Ministry of Health of Ukraine No. 455 dated 02.07.2014. "Unified clinical protocol of emergency, primary, secondary (specialized) and tertiary (highly specialized) medical assistance and medical rehabilitation of patients with acute coronary syndrome with elevation of the ST segment, based on clinical, electrocardiographic and biochemical criteria" [8]. Diagnosis of DM type 2 was determined according to the general recommendations of the American Diabetes Association (ADA) and the European Association for the Study of Diabetes (EASD). Duration of type 2 diabetes on the basis of outpatient card data was 3-10 years.

The exclusion criteria were rheumatologic, oncological diseases, connective tissue disease, pituitary and hypothalamic disease, thyroid gland disease, and symptomatic hypertension.

Research results. The state of CA in patients with AMI is analyzed depending on the presence or absence of DM type 2. In the group of patients with isolated AMI, two and multi-vessel lesions of CA were found, while the proportion of cases of two-vessel lesions of CA (14 cases / $43.8 \%$ ) twice exceeded this in case of mono-vascular lesions (7 cases / 21.8\%) and was comparable with a high incidence of multi-vessel lesions (11 cases / 34.4\%).

In patients with AMI in the presence of concomitant type $2 \mathrm{DM}$, the proportion of cases of multi-vessel lesions (23 cases / 82.1\%) was four times higher than that of patients with dual-vascular changes ( 5 cases / 17.9\%) in the absence of a cohort of patients with mono-vascular lesions. The results are presented in Table 1.

Table 1. Severity of damage to coronary artery arteries in patients with AMI depending on the presence or absence of concomitant DM type 2.

\begin{tabular}{|l|l|l|l|l|l|}
\hline \multicolumn{2}{|l|}{ Mono-vascular lesion } & \multicolumn{2}{l|}{ Dual-vascular lesions } & \multicolumn{2}{l|}{ Multiple lesions } \\
\hline $\begin{array}{l}\text { Absence of } \\
\text { DM type 2 }\end{array}$ & Availability of & Absence of & $\begin{array}{l}\text { Availability of } \\
\text { DM 2 type }\end{array}$ & $\begin{array}{l}\text { Absence of } \\
\text { DM type 2 }\end{array}$ & $\begin{array}{l}\text { Availability of } \\
\text { DM 2 type }\end{array}$ \\
\hline $\begin{array}{l}7 \text { cases } \\
21,8 \%\end{array}$ & - & 14 cases & $\begin{array}{l}5 \text { cases } \\
17,9 \%\end{array}$ & $\begin{array}{l}11 \text { cases } \\
34,4 \%\end{array}$ & 23 cases \\
$81,1 \%$
\end{tabular}

When comparing patients with and without DM type 2, it was found that, according to coronary angiography data, multivessel defeat was significantly more common in the presence of comorbidity of AMI and DM type 2 and was seen in 23 cases, which is $82.1 \%$, compared to 11 cases, which corresponds to $34,4 \%$.

Table 2 provides information on the location of infarction-dependent arteries and information on the mean value of hemodynamically significant and hemodynamically insignificant stenosis in patients with AMI depending on the presence or absence of concomitant DM type 2.

The infarction-dependent artery in most cases was LAD, a defeat of which was found in 18 patients in the group with comorbidity of AMI and DM type 2, which is $64.2 \%$ of all cases of acute coronary event. Similar results were obtained when analyzing the state of coronary artery in patients with AMI without DM type 2. In patients of this cohort - 20 patients, infarction -dependent artery was precisely LAD, which is $62.5 \%$ of all cases. The defeat of RCA was detected in 9 patients with a combined course of AMI and DM type $2(32.1 \%)$ and 8 patients with isolated AMI (25\%). Among the major arteries, occlussion of CX was the least frequently noted, both in the group of patients with AMI and DM type 2, and in the group of isolated AMI ( 1 case/12.5\% and 4 cases/12.1\% respectively). 
Table 2. Infarction-dependent arteries, hemodynamically significant and insignificant stenosis in patients with AMI in the presence or absence of DM type 2.

\begin{tabular}{|c|c|c|c|c|}
\hline \multicolumn{5}{|c|}{ Patients with AMI $(\mathrm{n}=60)$} \\
\hline Localization & $\begin{array}{l}\text { Presence of DM } \\
\text { type } 2\end{array}$ & $\begin{array}{l}\text { Infarction- } \\
\text { dependent CA }\end{array}$ & $\begin{array}{l}\text { Average value of } \\
\text { hemodynamically } \\
\text { significant stenoses, } \\
\%\end{array}$ & $\begin{array}{l}\text { Average value of } \\
\text { hemodynamically } \\
\text { insignificant } \\
\text { stenoses, } \%\end{array}$ \\
\hline \multirow[t]{2}{*}{ RCA } & $\begin{array}{l}\mathrm{DM}+ \\
(\mathrm{n}=28)\end{array}$ & $9 / 32,1 \%$ & $84,75 \%$ & $20 \%$ \\
\hline & $\begin{array}{l}\mathrm{DM}- \\
(\mathrm{n}=32)\end{array}$ & $8 / 25 \%$ & $82,63 \%$ & - \\
\hline \multirow[t]{2}{*}{ LAD } & $\begin{array}{l}\mathrm{DM}+ \\
(\mathrm{n}=28)\end{array}$ & $18 / 64,2 \%$ & $91,36 \%$ & $55 \%$ \\
\hline & $\begin{array}{l}\mathrm{DM}- \\
(\mathrm{n}=32)\end{array}$ & $20 / 62,5 \%$ & $88,33 \%$ & $55 \%$ \\
\hline \multirow[t]{2}{*}{ CX } & $\begin{array}{l}\mathrm{DM}+ \\
(\mathrm{n}=28)\end{array}$ & $1 / 3,7 \%$ & $87,5 \%$ & $45 \%$ \\
\hline & $\begin{array}{l}\mathrm{DM}- \\
(\mathrm{n}=32)\end{array}$ & $4 / 12,5 \%$ & $83,09 \%$ & $56 \%$ \\
\hline
\end{tabular}

The mean value of hemodynamically significant stenoses ranged from $82.63 \%$ to $91.36 \%$ when analyzing the results of coronary angiography of major CA in patients with AMI in the presence or absence of DM type 2 and probably did not differ depending on the localization of the defeat RCA, LAD and CX. Similar results were obtained regarding hemodynamically insignificant stenoses, where the mean value was within the range of $45-56 \%$ for LAD and CX. Lower parameters were in RCA and amounted to $20 \%$ in the group with comorbidity of AMI and DM type 2 . The proportions of hemodynamically significant stenoses outweighed the proportions of hemodynamically insignificant stenoses in patients of both groups.

That is, the majority of patients with AMI in the presence or absence of concomitant DM type 2 is characterized by a predominance of the proportion of patients with occlusion of LAD. Such results are consistent with the data of world medical literature. The results of long-term observations indicate that most often atherosclerotic lesions were observed in LAD (60\% of cases) and RCA was on the second place (24-25\% of cases) [7]. Our study also noted a similar trend.

Thus, the process of atherogenesis in patients with a combined course of AMI and DM 2 type proceeds more aggressively, resulting in multi-vessel lesions of CA. At the same time, the localization of atherosclerotic lesions did not reveal any significant differences between patients with isolated AMI and the comorbidity of AMI and DM 2 types.

Conclusions. The proportion of cases with multi-vessel lesions of coronary arteries exceeded the proportion of cases with one and two-vessel lesions of coronary arteries in patients with acute myocardial infarction and DM type 2 . The vast majority of cardiovascular events, namely $64.2 \%$ in patients with combined incidence of acute myocardial infarction and DM type 2 and $62.5 \%$ in the group of patients with isolated acute myocardial infarction, was due to occlusion of LAD. Mean values of both hemodynamically significant and hemodynamically insignificant stenoses in patients with comorbidity of AMI and DM type 2 were appropriate in patients with isolated AMI, regardless of the localization of the lesion. In addition, in the group of patients with comorbidity there is a more distinct violation compared with patients with isolated acute myocardial infarction by the percentage of patients with a multicentric lesion $-81.2 \%$ vs. $34.4 \%$, respectively.

\section{REFERENCES}

1. Гандзюк В. А. Аналіз захворюваності на ішемічну хворобу серця в Україні / В. А. Гандзюк // Український кардіологічний журнал. - 2014. - №3. - С. 45-52.

2. Коваленко В. М., Корнацький В. М. Проблеми здоровя і медичної допомоги та модель покращення в сучасних умовах (посібник) / В. М. Коваленко, В. М. Корнацький [та ін.] // ДУ «Національний науковий центр «Інститут кардіології імені акад. М. Д. Стражеска». - К., 2016. - 261 с.

3. Кравчук Н. Г. Показники здоров'я населення та використання ресурсів охорони здоров'я в Україні за 2013-2014 роки / Н. Г. Кравчук, І. Є. Стешенко, Н. Г. Руденко [та ін.] // Аналітично-статистичний довідник. - К., 2015. -325 с. 
4. Mozaffarian D., Benjamin E.J., Go A.S. et al. Heart disease and stroke statistics - 2016 update: a report from the American Heart Association. // Circulation. - 2016. - Vol. 133 (4). - P. 38-360.

5. Соколов М.Ю. и соавт. Реєстр перкутанних коронарних втручань: розширений порівняльний аналіз, реперфузійна терапія в Україні, Сервей ПКВ - 2015. // Серце і судини. - 2015. - №3. - С. 7-29.

6. Tavakol M., Ashraf S., Brener S.J. Risks and complications of coronary angiography: a comprehensive review. // Glob J Health Sci. - 2012. - Vol. 4. - P. 65-93.

7. Oshepkova E.V., Efremova Yu. E., Karpov Yu. A. 2013. Zabolevaemost' i smertnost' ot infarktamiokarda v RF v $2000-2011$ гг. Terapevticheskiy archiv. 4:4-10.

8. Unified clinical protocol of emergency, primary, secondary (specialized) and tertiary (highly specialized) medical care and medical rehabilitation of patients with acute coronary syndrome with elevation of segment ST [Internet]. Kyiv: Ministry of Healthcare of Ukraine; 2014 Jul 02 No. 455 [cited 2018 Mar 31]. Available from http://mtd.dec.gov.ua/images/dodatki/2014_455_GKS/2014_455nakaz_GKS.pdf. [in Ukrainian]. 